\title{
Discourse Analysis of Questions in Teacher Talk
}

\author{
Laleh Fakhraee Faruji \\ Department of Literature and Foreign Languages, Islamic Azad University, Science and Research Branch, Tehran, Iran \\ Email: Fakhraeelaleh@yahoo.com
}

\begin{abstract}
This study is an investigation of certain aspects of classroom verbal interaction with a focus on description and analysis of questions in teacher talk. Transcriptions of recorded classroom sessions were analyzed to identify the type of the questions used by an Iranian EFL teacher, teaching in a language institute in Iran. After data analysis of 8 sessions of instruction, the researcher identified four categories of teacher questions and their related frequency across the discourse of teacher talk.
\end{abstract}

Index Terms - discourse, initiation-response-evaluation (IRE), teacher talk

\section{INTRODUCTION}

Classroom discourse has been analyzed by many researchers in order to improve the quality of teaching and training. Most commonly referred interaction analysis systems were developed by (Flanders, 1970; Freiberg, 1981, \& Brown, 1975, as cited in Nasir \& Abdul Majid Khan, 2006).

Cazden (2001, p. 55) argued that in recent discussions there has been an emphasis on the shift to more self selection by students, a move from pre-determination of turns by the teacher to more local management of turn taking during speaking. According to him "with this shift, classroom talk becomes more like informal conversation, not the same as conversation, because there is still the large group of potential speakers and the educational necessity to stick to an agenda".

Cazden (2001) also claimed that the previous pattern of classroom discourse; Initiation, Response, and Evaluation (IRE) have been the "default pattern" or the "unmarked" one which seems to be natural at least to some teachers (p. 53). In this pattern the learners are often limited to a responding role with only one chance of speaking and there may be few opportunities for learners to practice communicative strategies (Jia, 2005). Cazden (2001) also raised the awareness of more marked, non-default patterns of teacher-student interaction which reflect differences in educational purposes for talk; number of participants; medium of interaction (electronic mail instead of oral); and cultural differences among students.

Much of the IRE discourse studied has been conducted in elementary classrooms where known-answer questions are common. Therefore IRE discourse has been widely criticized for its development of a model of knowledge that views learning as the collection of a series of facts which can be elicited (or recalled) when needed. Greenleaf \& Freedman (1993) referring to these critics, suggested an approach to analyze classroom talk that aims to account for the intellectual work of the classroom. The focus was on a teacher-led, whole-class activity that IRE exchanges, but that does not function to test students' knowledge. Rather, the talk, although not conversational in its structure, seems to engage students in constructing knowledge and in collaborative problem-solving.

According to Nasir \& Abdul Majid Khan (2006) the classroom interaction has gone through many fundamental shifts since the development of interaction analysis systems more than forty years ago. Present day classrooms are more students oriented, activity based and demanding in practice. Thus requiring teachers to be more 'responsive, spontaneous and critical' to create and maintain a classroom environment serving the learner's needs. The changing needs were identified by Newton (2002, as cited in Nasir \& Abdul Majid Khan, 2006) to describe the needs of the today's classrooms by designing a beneficial framework for effective classroom talk in science classroom which promotes student thinking.

In a related study, Nathan, Kim, and Grant (2009) reported on comparing the structure of classroom discussions in a middle school mathematics classroom before and after teacher participation in professional development activities aimed at enhancing students' classroom participation and the co-construction of mathematical ideas. They showed that changes in the classroom led to identifiable changes in discourse structure. In particular, decreasing the teacher's mathematical authority led to a reduction in traditional teacher-led initiation-response-evaluation (IRE) patterns, and to increases in student-led initiation-demonstration-evaluation (IDE) patterns.

The quality of the classroom environment is made up of a host of varied components. "As long as we are aware of the vast repertoire of techniques that are at our disposal, it is up to us to choose the specific ones that we will apply, based on the specific needs that arise in our concrete circumstances"(Dornyei, 2007, p. 730).

To fulfill the purpose of this study, the following questions were raised:

What is the frequency of the occurrence of different types of questions (e.g. factual, empirical, productive, and evaluative) in the discourse of an Iranian EFL teacher talk? 


\section{TEACHER TALK}

Walsh (2002) argued that maximizing learner involvement seem to be beneficial to second language acquisition. According to him teachers' ability to control their use of language is considered to be as important as their ability to select appropriate methodologies.

He examined the ways in which teachers construct or obstruct learner participation in classroom interaction, through their choice of language. By construction he meant "increasing learning potential" which he claimed can be done through activities like, direct error correction, content feedback, checking for confirmation, extended wait time, and scaffolding. Obstruction was defined by him as "reducing learning potential" which according to him, can be done through turn completion, teacher echo, teacher interruptions.

From the lesson extracts he identified a number of ways in which teachers can improve their teacher talk to facilitate and optimize learner contributions as follow.

1. To examine more closely the link between pedagogic purpose and language use.

2. To avoid 'filling in the gaps' in the discourse of the EFL classroom.

3. To raise their awareness of their language use in the classroom by making audio- and video-recordings of their lessons, and analyzing the transcripts.

4. Devoting more time by education programs to provide the most beneficial ways of language use in the classroom.

5. To understand more fully the qualitative aspects of language use in order to come up with a set of guidelines which constitute 'good practice' in language use in the classroom.

Xiao-hui (2010) in his study of analysis of teacher talk, argued that teachers should consciously improve their questioning behavior by providing an information gap between the teacher and the students. The gap is better to be related to a topic that is relevant to the learner's lives so that can stimulate their interests, and can require a level of thinking that stretches the students intellectually.

Lee (2007) provided an alternative approach towards third turn position in teacher talk through traditional initiation-response-evaluation (IRE). He emphasized that describing the third turn IRE in its traditional sense is just an oversimplification. He clarified that third turn cannot be explained just by using blanket terms such as 'evaluation,' 'feedback,' or 'follow-up. Rather he provided an analytic focus on the third turn position which is clear in the following quotation from his article:

"The analytic focus on the third turn position was not intended to capture the inherent essential characteristics contained in them. Rather, the third turn is viewed as a place holder that opens up an analytic possibility for describing the communicative acts that teachers display. The third turn position is particularly important because its relevance and influence take shape across the contingencies generated by the students' second turn, which itself is contingent upon the prior turn by the teacher."

Sharpe (2008) in his study examined in detail the teaching practices of a teacher regarded by colleagues and students as a 'good' teacher. Through detailed analysis of transcripts, a number of teacher talk strategies have been identified which support students in their history course. These strategies include:

o repeating, recasting and appropriation to develop technical language;

o cued elicitation to encourage students to jointly construct ideas and also check they are still following the teachers' line of reasoning that is being developed;

$\circ$ modifying questioning to extend or reformulate student's reasoning and create more complex connections and engage them in the investigation process;

o using low control moves to encourage students to develop their own ideas;

o using metacomments to create conceptual hooks that summarize key concepts that have been established;

o recycling ideas through busy clusters of words.

Other researchers also investigated the classroom discourse and teacher talk from different perspectives. To name a few among others the researcher can refer to Andrzejewski \& Davis (2008); Cullen (2002); Inceçay (2010); Nunn (1999); Qian, Tian, \& Wang (2009), and Yoshida (2008).

\section{QUESTIONS IN TEACHER TALK}

Long and Sato (1983, as cited in Shim, 2007) identified two types of questions that may be asked by teachers in their classrooms; display questions, and referential questions. They compared the number of 'display questions' (questions that teachers know the answer to and which are designed to elicit or display particular structures) and 'referential questions' (questions that teachers do not know the answers to) in naturalistic and classroom discourse. They found that in naturalistic discourse, referential questions are more frequent than display questions, whereas display questions are much more frequent in whole-class teaching in ESL classrooms.

$\mathrm{Wu}$ (1993) claimed that both display and referential questions have important functions to perform in language teaching and learning, and therefore their use can have a place in the ESL classroom. However, the use of different types of teach $\neg$ er questions does not guarantee that the quantity or quality of classroom interaction will be improved. What is important is the questioning strategies used by the teacher in order to elicit oral responses from students and to develop their grammatical competence. 
Wu (1993) suggested questioning can be one of the ways for eliciting output. His analysis demonstrated that ref-erential questions do not necessarily lead to more output from learners, but appropriate questioning strategies, e.g. probing, do. He also added "Teach $\neg$ ers also need to know that in some classrooms, it may not be too helpful to expect a voluntary answer to a general question. Students, especially the shy ones, may need to be nominated, at least occasionally".

Nasir \& Abdul Majid Khan (2006) to determine the shift towards constructivist practice, examined the changes in teacher talk and students talk over a period of two years. Data collection included all lessons about a particular topic for years 2001 and 2003 from 78 science students of grade five in a public school. Lesson's video recordings were converted into protocol and analyzed. The analysis was conducted by categorizing the class discourse in teacher, student and monitoring talk. Monitoring talk was further analyzed to examine the level and type of questions used by teacher to monitor students' learning progress. Results showed an improvement towards constructivist practice in terms of increase in the share of student talk by $10 \%$ compared to 2001 . Teacher talk in both cases was still more than $50 \%$ but it reduced from $67 \%$ in 2001 to $57 \%$ in 2003 . Consequently, student talk increased from $33 \%$ in 2001 to $43 \%$ in 2003 . He argued that this change may not seem satisfactory but is encouraging.

\section{Method}

In this study the researcher tried to analyze the teacher talk of an Iranian EFL teacher during nine 45 minute sessions of instruction through observation, in order to identify the type of questions was used by her during the class sessions. Some sessions were audiotaped, and were later transcribed by the researcher for the purpose of data analysis.

\section{A. Participants}

The participant was an Iranian EFL teacher in a language institute in Iran who has 8 years of experience and has got her MA degree in TEFL two years ago. Ten students participated in the class. They were studying the last 4 units of the third book of "Interchange Series", the blue one. The book "504 Absolutely Essential Words" and some idioms were also used by the teacher as subsidiary material. It is worth mentioning that it was the second year that the teacher has been teaching to this particular group of learners.

\section{B. Instrument}

The data were collected during 8 sessions of observations, samples of them has been audiotaped by the researcher.

\section{Procedure}

In this study monitoring talk (a sub-category of teacher talk) was analyzed to examine the type of questions used by the teacher to monitor students' learning progress.

Following framework for data analysis, was developed for the present study by adapting the three categories of class talk (tuning talk, connecting talk, and monitoring talk) suggested by Newton (2002, as cited in Nasir \& Abdul Majid Khan, 2006). Table 1 describes these categories for their content and scope.

Classroom discourse is mainly divided into two categories i.e. teacher talk and student talk. The sub-categories of teacher talk were adapted from Newton (2002, as cited in Nasir \& Abdul Majid Khan, 2006) but adjustments were made by Nasir \& Abdul Majid Khan (2006) to represent thoroughly the depth of classroom discourse. The adaptations are represented in Table 1 by italic characters.

\section{Framework for Analysis of Teacher Questions}

The data were analyzed by considering one utterance as basic unit of count. An utterance was defined by Nasir \& Abdul Majid Khan (2006) as "a complete meaningful segment of conversation dealing with single continuous idea". One word or one small utterance can be considered as the unit of analysis. The rationale for using an utterance as unit of analysis as was mentioned by Nasir \& Abdul Majid Khan (2006) was that the new constructivist focus is on the content of talk rather than the quantity of talk. They observed during their data analysis that sometimes a long sentence does not convey the meaning, which a single word can.

The analysis of teacher questions (sub-categorized as monitoring talk in class discourse) was made by using the categories suggested by Moore (2001, as cited in Nasir \& Abdul Majid Khan, 2006). He suggested four types of questions based on Bloom's taxonomy namely; factual, empirical, productive and evaluative. The description of question types by level is described in Table 2 . 
TABLE 1.

SUBCATEGORIES OF TEACHER TALK

\begin{tabular}{|c|c|c|c|}
\hline \multirow{4}{*}{ 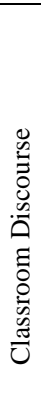 } & \multirow{4}{*}{ 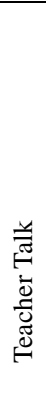 } & Subcategories & Explanation \\
\hline & & Tuning & $\begin{array}{l}\text { Usually at the beginning of the lesson but can be anything during the lesson if the lesson comprises of more than one } \\
\text { activities of different focus. This includes encouraging students to recollect their mental resources (like experiences, } \\
\text { previous learning, etc.), checking sufficiency and quality of those resources, scaffolding where necessary, drawing the } \\
\text { aim of lesson and getting students ready to enter activity by accepting and valuing their ideas and experiences. }\end{array}$ \\
\hline & & Connecting & $\begin{array}{l}\text { It may appear in any part of the lesson. Mostly about helping to establish the link between current learning, already } \\
\text { learned and future learning by exploring patterns, relationships, reasons and causes. It involves accepting student's } \\
\text { ideas and leading them to extend those ideas by putting immediately verifiable challenges. It is also meant to keep the } \\
\text { students focused on the lesson objectives and see the learning activity in that context. }\end{array}$ \\
\hline & & Monitoring & $\begin{array}{l}\text { Mostly occur at the beginning and end of the lesson. At the beginning for judging the previous knowledge and at the } \\
\text { final part for the understanding of immediate task. It comprises of the teacher questions about content, process, and } \\
\text { value judgment of the learned. }\end{array}$ \\
\hline
\end{tabular}

TABLE 2.

DESCRIPTION OF QUESTION TYPES

\begin{tabular}{|c|c|c|c|}
\hline Category & $\begin{array}{l}\text { Bloom's } \\
\text { Taxonomy }\end{array}$ & Type of thinking & Examples \\
\hline Factual & $\begin{array}{l}\text { Knowledge or } \\
\text { comprehension }\end{array}$ & $\begin{array}{l}\text { Student simply } \\
\text { recall information }\end{array}$ & $\begin{array}{l}\text { Define ...? } \\
\text { Who was ...? } \\
\text { What did the text say } \\
\ldots \text { ? }\end{array}$ \\
\hline Empirical & $\begin{array}{l}\text { Application or } \\
\text { analysis }\end{array}$ & $\begin{array}{l}\text { Student integrate } \\
\text { and analyzes given } \\
\text { or recalled } \\
\text { information }\end{array}$ & $\begin{array}{l}\text { Compare ...? } \\
\text { Explain in your words } \\
\ldots \text { ? } \\
\text { Calculate the ...? }\end{array}$ \\
\hline Productive & Synthesis & $\begin{array}{l}\text { Students thinks } \\
\text { creatively and } \\
\text { imaginatively and } \\
\text { produces } \\
\text { something unique }\end{array}$ & $\begin{array}{l}\text { What will life be like } \\
\text { What's good name for } \\
\text { ?h? } \\
\text { How could we ...? }\end{array}$ \\
\hline Evaluative & Evaluation & $\begin{array}{l}\text { Students make } \\
\text { judgment or } \\
\text { express value }\end{array}$ & $\begin{array}{l}\text { Which method is most } \\
\text { suitable ...? } \\
\text { Why do you favor ...? } \\
\text { Who is the best ...? }\end{array}$ \\
\hline
\end{tabular}

\section{DATAANALYSIS}

At the beginning of each session some routine questions were asked by the teacher, and then the teacher calls the roll. Following extract contains some typical examples of questions of this type. It is worth mentioning that these types of questions were not taken into account in this study:

T: What's up?

T: How's everything? Goes well?

Ss: Not bad.

T: How was your holiday?

S1: Very good.

T: OK. Let's start. Today we have the quiz? [Then teacher starts calling the roll]

T: Aida is absent?

S2: Yes, she goes to a wedding party.

T: Wedding party! Yes, I remember. She told me. OK, let's start. Page 108, word power.

Am I right? Yes?

Ss: Yes.

T: Oh Ok. But do you have any problems with the last lesson?

As mentioned, these kinds of questions were not the main concern of this study. What is more important to the researcher was to analyze the teacher questions with respect to the four types of questions in the classification provided by Moore (2001 as cited in Nasir \& Abdul Majid Khan, 2006), based on Bloom's taxonomy, namely; factual, empirical, productive and evaluative.

\section{A. Factual Questions}

In these types of questions which refer to knowledge or comprehension questions, students are asked to simply recall information (Moore, 2001, as cited in Nasir \& Abdul Majid Khan, 2006). He provided the following examples:

$\diamond$ Define....

$\diamond$ What did the text say?

$\diamond$ Who was ...?

Factual questions were seemed to be the mostly used type of questions by the teacher in this study. Examples of these questions were as follow:

$\diamond$ What is the meaning of article?

$\diamond$ What does it mean 'feeling run down'?

$\diamond$ What's going on in that listening? 
You know 'parking lot'?

Remember the meaning of 'urban'?

\section{B. Empirical Questions}

In these types of questions which refer to application or analysis questions, students integrate or analyze given or recalled information (Moore, 2001, as cited in Nasir \& Abdul Majid Khan, 2006). He provided the following examples:

$\diamond$ Compare ... with ....

$\diamond$ Explain in your words....

A few numbers of these questions were used by the teacher in this study. Examples of these questions were as follow:

$\diamond$ What is a financial problem?

$\diamond$ Can you use this word in a sentence?

\section{Productive Questions}

In these types of questions learners think creatively and imaginatively and produce something unique (Moore, 2001, as cited in Nasir \& Abdul Majid Khan, 2006). He provided the following examples:

$\diamond$ What will life be ...?

$\diamond$ What's good name for ...?

$\diamond$ Why do you use proverbs?

Following are some examples of the productive questions used by the teacher in this study:

$\diamond$ Do you remember one of your white lies?

$\diamond$ What do proverbs tell us?

$\diamond$ What rules are there in a library?

$\diamond$ What about an art museum?

$\diamond$ What about an aeroplane?

\section{Evaluative Questions}

In these types of questions students make judgments or express value (Moore, 2001, as cited in Nasir \& Abdul Majid Khan, 2006). He provided the following examples:

$\diamond$ Which method is most suitable?

$\diamond$ What do you favor ...?

$\diamond$ Who is the best ...?

In some cases the teacher provided the learners with a hypothetical situation and asked them about what they would do in that particular situation. Examples are as follow:

$\diamond$ You forget your best friend's birthday. What would you do?

$\diamond$ If someone gives some ugly present to you, what would you do?

$\diamond$ Any other suggestions?

$\diamond$ What else can you do?

$\diamond$ A person who was cheating got a higher mark than you. What would you do?

$\diamond$ You have found a diamond ring. What would you do?

$\diamond$ What would you do if you see a burglar Bahar?

$\diamond$ Did you ever lose anything? What did you do?

\section{RESUlts AND DisCUSSION}

The researcher analyzed the observations and tape recordings and tried to categorize the questions used by the teacher by type and then counted the questions in each category and calculated the relative frequency of each type. Table 3 shows the comparative distribution of the questions by type.

TABLE 3.

CATEGORIZATION OF QUESTION TYPES IN TEACHER TALK

\begin{tabular}{|l|l|l|l|l|l|}
\cline { 2 - 6 } \multicolumn{1}{c|}{} & Factual & Empirical & Productive & Evaluative & Total \\
\hline Number & 68 & 8 & 18 & 35 & 129 \\
\hline Percent & $52.71 \%$ & $6.20 \%$ & $13.95 \%$ & $27.13 \%$ & $100 \%$ \\
\hline
\end{tabular}

As is shown in the table, factual questions are the mostly used questions by the teacher in this study. $52.71 \%$ of the questions used by the teacher were shown to be factual questions which were mostly related to asking the meaning of a word. Factual questions were used by the teacher particularly when she was working on the vocabulary book, "504 Absolutely Essential Words".

The second highly used type of questions was shown to be Evaluative questions which were used with a proportion 
of $27.13 \%$ in her talk. Using these types of questions, the teacher tried to participate the learners in classroom discourse by posing questions which seemed to be interesting for them. Learners were given opportunities to exchange their opinions and talking about their personal experiences by evaluating different situations provided by the teacher.

Productive types of questions constituted $13.95 \%$ of the total questions posed by the teacher. These types of questions made the students think and use their world knowledge to answer the questions. They require them to use their imagination and to produce an appropriate answer. These types of questions also seemed to be beneficial in encouraging the learners to participate in the classroom discourse by producing long turns.

Empirical questions were the type of questions which were used least by the teacher in this study. These questions are not as challenging as productive and evaluative questions. The teacher used them with a proportion of $6.20 \%$ in her talk.

\section{CONCLUSION}

Although most of the questions posed by the teacher were shown to be factual questions, the teacher seemed to be of those types of teachers who try to promote negotiation of meaning in the classroom. As mentioned earlier most of the factual questions were posed during the teaching of vocabulary book, "504 Absolutely Essential Words" which were an obligatory part of the syllabus as determined by the institute.

The teacher seemed to be very interested in productive and evaluative types of questions which together constitute a considerable part of her discourse, about $41.08 \%$. By using these types of questions, the she tried to provide a friendly atmosphere in which students feel comfortable in expressing their ideas and personal experiences and evaluating each other's experiences. The teacher herself sometimes shares her experiences with the learners and encourages them to talk about their own ones.

The type of questions used by a teacher can have a very important role in constructing a facilitative environment for language learning. The teacher in this study by posing challenging and interesting questions tried to involve the learners in classroom discussions by making them participate in long turns.

\section{ACKNOWLEDGMENT}

The author wishes to thank Dr. Parviz Maftoon, her professor, for providing very supportive guidelines. She also wants to thank Mrs Robab Gholizadeh who was the main participant of this study.

\section{REFERENCES}

[1] Andrzejewski, C. E., \& Davis, H. A. (2008). Human contact in the classroom: Exploring how teachers talk about and negotiate touching students. Teaching and Teacher Education, 24, 779-794.

[2] Cazden, C. B. (2001). Classroom discourse: The language of teaching and learning. Netherlands: Heinemann Educational Books.

[3] Cullen, R. (2002). Supportive teacher talk: The importance of the F-move. ELT Journal, 56(2), 117-127.

[4] Dornyei, Z. (2007). Creating a motivating classroom environment. In J. Cummins \& Ch. Davison (Eds.), International handbook of English language teaching (pp. 719-731). New York: Springer Science + Business Media, Inc.

[5] Greenleaf, C., \& Freedman, S. W. (1993). Linking classroom discourse and classroom content: Following the intellectual work in a writing lesson. Retrieved November 15, 2010 from www.gse.berkeley.edu/faculty/sw

[6] Inceçay, G. (2010). The role of teacher talk in young learners' language process. Procedia Social and Behavioral Sciences, 2 , 277-281.

[7] Jia, A. (2005). Feedback in the IRF discourse model in foreign language classroom. Sino-US English Teaching, 2 (7), $25-29$. Retrieved November 15, 2010 from www.linguist.org

[8] Lee, Y. (2007). Third turn position in teacher talk: Contingency and the work of teaching. Journal of Pragmatics, 39, 180-206.

[9] Nasir, M., \& Abdul Majid Khan, R. (2006). Constructivist classroom: Elements of class discourse as measure of constructivist practice. Bulletin of Education \& Research, 28(1), 23- 34.

[10] Nathan, M. J., Kim, S., \& Grant, T. S. (2009). Instituting change in classroom discourse structure: Human and computer based motif analysis. Retrieved November 15, 2010 from http://www.wcer.wisc.edu/

[11] Nunn, R. (1999). The purpose of language teachers' questions. International Review of Applied Linguistics, 37(1), 23-34.

[12] Qian, X., Tian, G., \& Wang, Q. (2009). Code switching in the primary EFL classroom in China: Two case studies. System, 37, 719-730.

[13] Sharpe, T. (2008). How can teacher talk support learning? Linguistics and Education, 19, 132-148.

[14] Shim, J. H. (2007). Teacher talk as strategies in the classroom. Korea Education Research, 25, 37-88.

[15] Xiao-hui, X. (2010). Analysis of teacher talk on the basis of relevance theory. Canadian Social Science, 6(3), 45-50.

[16] Yoshida, H. (2008). An analysis of discourse in the EFL classroom. Osaka Keidai Ronshu, 59(2), 1-14.

[17] Walsh, S. (2002). Construction or Obstruction: Teacher talk and learner involvement in the EFL classroom. Language Teaching Research, 6(1), 3-23.

[18] Wu, K. (1993). Classroom interaction and teacher questions revisited. RELC Journal, 24, 49-68. 


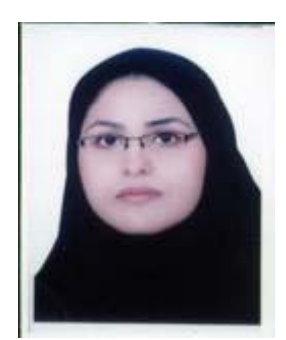

Laleh Fakhraee Faruji was born in Quchan, Iran. She is a Ph.D candidate in TEFL at Islamic Azad University, Science and Research Branch, Tehran, Iran. She received her MA degree in TEFL from Islamic Azad University, North Tehran, Iran in 2008. She is a faculty member of English department at Islamic Azad University, Shahre Qods Branch, Tehran, Iran. Her recent publications include: 'Forgetting vs. Remembering: Implications in Language Teaching', ELT Weekly, 2011, issue 83, and 'Using Learner Corpora in Scandinavian Countries: Norway \& Sweden', INTED conference proceedings (2011). Her current research interests include language learning, second language acquisition, psycholinguistics, and language teaching methodology. 